\title{
KONTRIBUSI PEMUNGUTAN PAJAK OLEH BENDAHARA PENGELUARAN PEMERINTAH TERHADAP PENERIMAAN PAJAK PENGHASILAN PADA KPP PRATAMA MANADO TAHUN 2013-2017
}

\author{
Elyakim Tande Padang ${ }^{1}$, Jullie J. Sondakh ${ }^{2}$, Lidia M. Mawikere ${ }^{3}$ \\ ${ }^{1,2,3}$ Jurusan Akuntansi, Fakultas Ekonomi dan Bisnis, Universitas Sam Ratulangi, Jalan Kampus Bahu \\ Malalayang, Kota Manado, 95115, Indonesia \\ Email: elyakimtandepadang@gmail.com
}

\begin{abstract}
Government Expenditure Treasurer is a party that carries out tax deduction from expenditures originating from State Revenue and Expenditure Budget or Regional Revenue and Expenditure Budget. This study aims to know the contribution of tax collection by the government treasurer of income tax revenues at the KPP Pratama Manado Year 2013-2017. The method of analysis in this research is quantitative associative by using contribution analysis technique. In accordance with the classification table of contribution criteria it can be seen that the rate of tax collection contribution by the Government Treasury is high or strongly contribute to income tax revenue in KPP Pratama Manado Year 2013-2017.
\end{abstract}

Keywords: Contribution of Tax Collection, Tax Receipts.

\section{PENDAHULUAN}

Bangsa Indonesia sudah lama mencanangkan gerakan pembangunan nasional. Menurut Yulaika (2014), "pembangunan nasional merupakan kegiatan yang berlangsung terus menerus dan bersinambungan yang bermanfaat untuk meningkatkan kesejahteraan rakyat baik yang bersifat material maupun spiritual. Kasim (2016) mengatakan, "tidak bisa dipungkiri bahwa penerimaan negara yang terbesar adalah dari sektor pajak, dan sampai dengan sekarang pemerintah Indonesia belum juga mampu memanfaatkan dan memaksimalkan pendapatan negara dari hasil kekayaan bumi Indonesia secara mandiri dengan sebaik mungkin untuk kesejahteraan masyarakat, bangsa dan negara Indonesia. Dalam beberapa tahun terakhir ini perpajakan telah menjadi sumber penerimaan negara yang utama, pajak sebagai sumber penerimaan merupakan satu hal yang sangat wajar ketika sumber daya alam, khususnya minyak bumi tidak bisa diharapkan lagi. Penerimaan dari sumber daya alam memiliki umur yang terbatas, suatu saat akan habis dan tidak bisa diperbaharui. Berbeda dengan pajak yang mempunyai umur tidak terbatas, dengan melihat bahwa jumlah penduduk semakin bertambah.

Dalam APBN tahun 2016, penerimaan pajak yang meliputi PPh, PPN \& PPnBM, $\mathrm{PBB}$, dan Bea Materai mengambil porsi lebih dari Rp1.300 trilliun atau lebih dari $73 \%$ dari total penerimaan negara yang dianggarkan. Penerimaan tersebut bersumber dari penerimaan pajak-pajak, baik yang dibayar sendiri oleh Wajib Pajak maupun disetor oleh pihak lain melalui mekanisme pemotongan/pemungutan pajak (Direktorat Jenderal Pajak, 2016). Menunjuk pada ketentuan yang berlaku di bidang perpajakan, pihak yang melakukan pemotongan/pemungutan pajak atas pengeluaran yang berasal dari Anggaran Pendapatan dan Belanja Negara (APBN) atau Anggaran Pendapatan dan Belanja Daerah (APBD) adalah bendaharawan pemerintah. Tumbel (2017) menyatakan, "bendaharawan pemerintah adalah pemegang kas dan pejabat lain yang menjalankan fungsi yang sama. Dalam hal ini, bendaharawan harus mengetahui aspek-aspek perpajakan utamanya yang berkaitan dengan kewajiban untuk melakukan pemotongan atau pemungutan pajak Penghasilan serta Pajak Pertambahan Nilai. 
Dalam melaksanakan kewajiban tersebut, masyarakat juga bisa ikut serta dalam mengawasi bagaimana pelaksanaan pemotongan atau pemungutan pajak yang dilakukan oleh bendahara pemerintah. Bila bendahara lalai dalam menjalankan tugasnya, hal ini akan mengakibatkan berkurangnya penerimaan pajak sehingga akan menurunkan kemampuan Pemerintah untuk mengatasi pengangguran, kemiskinan, dan rencana pembangunan di Indonesia. Agar tidak menimbulkan kesalahan dalam pemotongan hingga pelaporan pajak maka pemahaman dari bendaharawan pemerintah dan pihak lain yang terkait, harus sesuai dengan ketentuan perpajakan yang berlaku.

Salah satu penerimaan pajak penghasilan pada KPP Pratama Manado adalah yang berasal dari pajak penghasilan yang dipotong dan/atau dipungut oleh bendaharawan pemerintah di wilayah kerja KPP Pratama Manado, yakni Kota Manado dan Kota Tomohon. Kantor Pelayanan Pajak Pratama Manado telah melakukan banyak usaha dan kegiatan seperti sosialisasi pajak untuk bendaharawan, pengawasan langsung terhadap data DTH/RTH, dan lain-lain guna meningkatkan penerimaan pajak penghasilan dari bendaharawan pemerintah. Supaya realisasi penerimaan pajak khususnya Pajak Penghasilan bisa tercapai maksimal dan stabil terus-menerus bahkan cenderung meningkat, maka analisis kontribusi pemungutan pajak oleh bendahara pemerintah perlu dilakukan.

\section{TINJAUAN PUSTAKA}

Konsep Dasar Akuntansi. Menurut Suwardjono (2014), "akuntansi adalah seperangkat pengetahuan dan fungsi yang berkepentingan dengan masalah pengadaan, pengabsahan, pencatatan, pengklasifikasian, pemrosesan, peringkasan, penganalisisan, penginterpretasian dan penyajian secara sistematik informasi yang dapat dipercaya dan berdaya guna tentang transaksi dan kejadian yang bersifat keuangan yang diperlukan dalam pengelolaan dan pengoperasian suatu unit usaha dan yang diperlukan untuk dasar penyusunan laporan yang harus disampaikan untuk memenuhi pertanggungjawaban pengurusan keuangan dan lainnya.

Konsep Dasar Pajak. Mardiasmo (2016:3) mengatakan, “menurut Undang-Undang Republik Indonesia Nomor 16 Tahun 2009 tentang perubahan keempat atas Undang-Undang Nomor 6 Tahun 1983 tentang Ketentuan Umum dan Tata Cara Perpajakan pasal 1 ayat (1), pajak adalah kontribusi wajib kepada Negara yang terutang oleh orang pribadi atau badan yang bersifat memaksa berdasarkan Undang-Undang, dengan tidak mendapatkan imbalan secara langsung dan digunakan untuk keperluan Negara bagi sebesar-besarnya kemakmuran rakyat.

Pajak Penghasilan. Mardiasmo (2016:163) mengatakan, menurut Undang-Undang Nomor 36 Tahun 2008 Pajak Penghasilan adalah pungutan resmi yang ditentukan kepada masyarakat dalam hidup berbangsa dan bernegara sebagai suatu kewajiban yang harus dilaksanakan. Penghasilan berdasarkan pasal 4 (1) Undang-undang No. 36 tahun 2008 adalah setiap tambahan kemampuan ekonomis yang diterima atau diperoleh Wajib Pajak, baik yang berasal dari Indonesia maupun luar Indonesia, yang dapat dipakai untuk konsumsi atau untuk menambah kekayaan Wajib Pajak yang bersangkutan, dengan nama dan dalam bentuk apapun.

Pemotongan Pajak Penghasilan Pasal 21. Menurut Sari (2013:25), "Pajak Penghasilan Pasal 21 adalah $\mathrm{PPh}$ yang harus dipotong oleh setiap pemberi kerja terhadap imbalan berupa gaji, upah, honorarium, tunjangan, penghargaan, maupun pembayaran lainnya, yang mereka bayar atau terutang kepada orang pribadi dalam negeri sehubungan dengan pekerjaan, jasa dan kegiatan yang dilakukan orang pribadi tersebut.

Pemungutan Pajak Penghasilan Pasal 22. Menurut Direktorat Jenderal Pajak (2016:14), "pemungutan Pajak Penghasilan Pasal 22 atau PPh Pasal 22 dilakukan sehubungan 
dengan pembayaran atas pembelian barang seperti: komputer, meubeler, mobil dinas, ATK dan barang lainnya oleh Pemerintah kepada Wajib Pajak penyedia barang.

Pemotongan Pajak Penghasilan Pasal 23. Menurut Direktorat Jenderal Pajak (2016:16), "pemotongan PPh Pasal 23 adalah cara pelunasan pajak dalam tahun berjalan melalui pemotongan pajak atas penghasilan yang dibayarkan oleh bendahara kepada pihak lain.

Pemotongan/Pemungutan PPh Pasal 4 ayat (2). Menurut Direktorat Jenderal Pajak (2016:20), "pemotongan atau pemungutan Pajak Penghasilan (PPh) Pasal 4 ayat (2) adalah cara pelunasan pajak dalam tahun berjalan antara lain melalui pemotongan atau pemungutan pajak yang bersifat final atas penghasilan tertentu yang ditetapkan dengan Peraturan Pemerintah.

Bendaharawan Pemerintah. Menurut Kamus Besar Bahasa Indonesia (Poerwadarminta, 2003) dalam (Tumbel, 2017), "bendaharawan adalah setiap orang yang diberi tugas menerima, menyimpan, membayar dan/atau menyerahkan uang atau surat berharga atau barang-barang negara. Secara sederhana bendaharawan adalah mereka yang bekerja di BUMN atau pemerintah, baik pusat maupun daerah yang mengelola APBN/APBD dan yang ditunjuk oleh atasannya untuk menjabat menjadi pejabat bendaharawan pemerintah dengan surat keputusan pengangkatan. Menurut Direktorat Jenderal Pajak (2016:1), "sesuai dengan ketentuan yang berlaku di bidang perpajakan, pihak yang melakukan pemotongan dan/atau pemungutan pajak atas pengeluaran yang berasal dari Anggaran Pendapatan dan Belanja Negara (APBN), Anggaran Pendapatan dan Belanja Daerah (APBD), atau Anggaran Pendapatan dan Belanja Desa (APBDes) adalah bendahara pemerintah. Termasuk dalam pengertian bendahara pemerintah antara lain bendahara pengeluaran, bendahara desa, pemegang kas, dan pejabat lain yang menjalankan fungsi yang sama. Sebagai pihak yang melakukan pemotongan dan/atau pemungutan pajak, bendahara pemerintah harus mengerti aspek-aspek perpajakan, utamanya yang berhubungan dengan kewajiban untuk melakukan pemotongan dan/atau pemungutan Pajak Penghasilan (PPh), Pajak Pertambahan Nilai (PPN), serta Bea Meterai. Secara umum, kewajiban perpajakan bagi bendahara pemerintah adalah mendaftarkan diri menjadi Wajib Pajak, melaksanakan pemotongan dan/atau pemungutan $\mathrm{PPh}, \mathrm{PPN}$ dan Bea Materai, serta melaksanakan penyetoran dan pelaporan pajak yang telah dipotong/dipungut.

Kontribusi. Sukrainisih dan Fajriana (2017) mengatakan, "menurut kamus besar bahasa Indonesia, kontribusi adalah uang iuran (kepada perkumpulan dan sebagainya) atau sumbangan. Sedangkan menurut Kamus Ekonom (T. Guritno 1992 hal.76), kontribusi adalah sesuatu yang diberikan bersama-sama dengan pihak lain untuk tujuan biaya, atau kerugian tertentu atau bersama. Indikator kontribusi adalah rasio antara realisasi pemungutan pajak bendaharawan dengan realisasi penerimaan pajak penghasilan.

Tabel 1. Klasifikasi Kriteria Kontribusi

\begin{tabular}{clc}
\hline Persentase & \multicolumn{1}{c}{ Tingkat Kontribusi } & Tanda/Kode \\
\hline$>4 \%$ & Dinyatakan bahwa sangat mempunyai kontribusi & SB \\
$3 \%-3,9 \%$ & Dinyatakan bahwa mempunyai kontribusi & $\mathrm{B}$ \\
$2 \%-2,9 \%$ & Dinyatakan bahwa cukup mempunyai kontribusi & $\mathrm{CB}$ \\
$1 \%-1,9 \%$ & Dinyatakan bahwa kurang mempunyai kontribusi & $\mathrm{KB}$ \\
$0 \%-0,9 \%$ & Dinyatakan bahwa tidak mempunyai kontribusi & $\mathrm{TB}$ \\
\hline
\end{tabular}

Sumber : Fuad Bawasir, 1999

Kontribusi Pemungutan/Pemotongan Pajak oleh Bendahara Pemerintah Terhadap Penerimaan Pajak Penghasilan. Salim dan Syafitri (2013) mengatakan, pajak merupakan salah satu penerimaan negara yang berpotensi besar dalam membiayai pengeluaran serta biaya negara yang dibebankan kepada masyarakat. Salah satu pajak yang di 
bebankan oleh pemerintah kepada masyarakatnya adalah Pajak Penghasilan. Dalam Pasal 1 UU No. 36 Tahun 2008, "pajak penghasilan adalah pajak yang dikenakan terhadap subjek pajak atas penghasilan yang diterima atau diperolehnya dalam tahun pajak. Menurut Wahyuni (2016), pemahaman dan kesadaran bendaharawan pemerintah dalam hal memotong dan/atau memungut, menyetor dan melaporkan pajak penghasilan dapat memberikan kontribusi yang tinggi terhadap realisasi penerimaan pajak sehingga penerimaan pajak dapat dioptimalkan.

\section{METODE PENELITIAN}

Jenis dan Sumber Data. Data yang digunakan adalah kualitatif dan kuantitatif. Yang dimaksud dengan dengan sumber data dalam penelitian adalah subyek dari mana data dapat diperoleh. Dalam penelitian ini penulis menggunakan dua sumber data yaitu: (1) sumber data primer, yaitu data yang langsung dikumpulkan oleh peneliti dari sumber pertamanya. Adapun yang menjadi sumber data primer dalam penelitian ini adalah kepala kantor, Account Representative Seksi Pengawasan dan Konsultasi, dan pelaksana Seksi Pengolahan Data dan Informasi; (2) sumber data sekunder, yaitu data yang langsung dikumpulkan oleh peneliti sebagai penunjang dari sumber pertama. Dapat juga dikatakan data yang tersusun dalam bentuk dokumen-dokumen. Dalam penelitian ini, tabelaris kontribusi pemungutan pajak bendahara terhadap penerimaan PPh Tahun 2013-2017 merupakan sumber data sekunder.

Metode Analisis. Teknik analisis data yang dipakai dalam penelitian ini adalah analisis kontribusi, merupakan analisis yang digunakan untuk mengetahui seberapa besar kontribusi yang dapat disumbangkan dari pemungutan pajak oleh bendaharawan pemerintah terhadap penerimaan pajak penghasilan pada KPP Pratama Manado, maka akan dibandingkan antara realisasi pemungutan pajak terhadap penerimaan $\mathrm{PPh}$.

\section{HASIL ANALISIS DAN PEMBAHASAN}

4.1. Hasil Analisis

Tabel 2. Target dan Realisasi Penerimaan Pajak Tahun 2013-2017

\begin{tabular}{clll}
\hline Tahun & Target & Realisasi & \% \\
\hline 2013 & $1,495,086,596,000$ & $1,300,095,865,993$ & 86.96 \\
2014 & $1,531,891,035,000$ & $1,376,485,199,547$ & 89.86 \\
2015 & $2,254,444,438,068$ & $1,764,264,767,384$ & 78.26 \\
2016 & $2,513,376,550,000$ & $1,695,818,923,076$ & 67.47 \\
2017 & $2,342,384,741,000$ & $1,598,045,301,053$ & 68.22 \\
\hline Jumlah & $\mathbf{1 0 , 1 3 7 , 1 8 3 , 3 6 0 , 0 6 8}$ & $\mathbf{7 , 7 3 4 , 7 1 0 , 0 5 7 , 0 5 3}$ & $\mathbf{7 6 . 3 0}$ \\
\hline
\end{tabular}

Sumber: KPP Pratama Manado (2018)

Berdasarkan Tabel 2 diatas, dapat diketahui bahwa target penerimaan pajak khususnya Pajak Penghasilan (PPh) dan Pajak Pertambahan Nilai mengalami peningkatan. Sedangkan untuk realisasi penerimaan pajak, mengalami peningkatan dari tahun 2013 sampai dengan tahun 2015. Namun pada tahun 2016, realisasi penerimaan pajak mengalami penurunan yang cukup besar sampai dengan tahun 2017. 
Tabel 3. Kontribusi Pemungutan Pajak Bendahara terhadap Penerimaan PPh Tahun 2013-2017

\begin{tabular}{ccrr}
\hline Tahun & $\begin{array}{c}\text { PPh yang dipotong/pungut oleh } \\
\text { Bendahara Pemerintah }\end{array}$ & $\begin{array}{c}\text { Penerimaan } \\
\text { PPh }\end{array}$ & $\begin{array}{c}\text { Kontribusi } \\
(\boldsymbol{\%})\end{array}$ \\
\hline 2013 & $20,742,874,689$ & $711,633,283,407$ & 2.91 \\
2014 & $67,213,349,159$ & $799,932,354,938$ & 8.40 \\
2015 & $93,608,165,642$ & $973,696,338,740$ & 9.61 \\
2016 & $170,501,422,748$ & $1,068,450,877,400$ & 15.96 \\
2017 & $129,866,665,643$ & $925,454,676,067$ & 14.03 \\
\hline Jumlah & $\mathbf{4 8 1 , 9 3 2 , 4 7 7 , 8 8 1}$ & $\mathbf{2 , 4 8 5 , 2 6 1 , 9 7 7 , 0 8 5}$ & \\
\hline
\end{tabular}

Sumber: KPP Pratama Manado (2018)

Berdasarkan Tabel 3 diatas, dapat diketahui bahwa pajak penghasilan yang dipotong dan/atau dipungut oleh Bendaharawan Pemerintah dan penerimaan pajak penghasilan di KPP Pratama Manado mengalami peningkatan dari tahun 2013 sampai dengan 2016, dan kemudian mengalami penurunan di tahun 2017.

\subsection{Pembahasan}

Berdasarkan hasil analisis kontribusi menggunakan rumus kontribusi pada tabel 3, diketahui bahwa nilai kontribusi pada tahun 2013 adalah sebesar 2,91\%. Apabila dibandingkan dengan tabel 1, maka dapat diketahui tingkat kontribusinya adalah cukup. Sedangkan pada tahun-tahun berikutnya, nilai kontribusi mengalami peningkatan. Sesuai dengan klasifikasi kriteria kontribusi maka dapat diketahui bahwa tingkat kontribusi pemungutan pajak oleh Bendahara Pemerintah adalah tinggi atau sangat berkontribusi terhadap penerimaan pajak penghasilan di KPP Pratama Manado.

Pada tahun 2013, nilai kontribusi pada Kantor Pelayanan Pajak Pratama Manado sangat kecil yaitu sebesar 2,91\%. Hal ini disebabkan antara lain kurangnya pemahaman dan pengetahuan perpajakan oleh bendahara-bendahara pemerintah di setiap satuan kerja yang dinaungi oleh KPP Pratama Manado, sehingga kurangnya pemungutan/penyetoran pajak oleh bendahara-bendahara pemerintah tersebut. Menurut Wahyuni (2016) dalam penelitiannya yang dilakukan di UIN Alauddin Makassar, pemahaman dan kesadaran bendahara pemerintah berperan penting dalam memotong, memungut, menyetor dan melaporkan pajak penghasilan, yang mana dalam pelaporan dan pembayaran pajak diperlukan kesadaran dan kejujuran wajib pajak bendahara tersebut. Bendahara memotong dan memungut pajak penghasilan sesuai dengan aturan yang berlaku dan melaporakan pajak dengan menggunakan surat pemberitahuan masa ke Kantor Pelayanan Pajak Pratama.

Pemahaman kepada wajib pajak yang luas untuk lebih memahami tentang pajak melalui sosialisasi dan penyuluhan mengenai pajak penghasilan dapat memberikan kontribusi kepada pemerintahan atau otoritas pajak sehingga dapat memberikan sehingga penerimaan pajak dapat dioptimalkan. Hal ini sesuai dengan salah satu tugas pokok dan fungsi dari Direktorat Jenderal Pajak yaitu memberikan sosialisasi dan penyuluhan kepada wajib pajak mengenai perpajakan. Pada tahun 2014, terjadi peningkatan penerimaan pajak penghasilan pada KPP Pratama Manado yang diikuti dengan meningkatkan jumlah pajak penghasilan yang dipotong/pungut oleh bendahara pemerintah. Hal ini disebabkan oleh dikeluarkannya Peraturan Menteri Keuangan Nomor 64/PMK.05/2013 tentang Mekanisme Pengawasan Terhadap Pemotongan/Pemungutan dan Penyetoran Pajak Yang Dilakukan Oleh Bendahara Pengeluaran Satuan Kerja Perangkat Daerah/Kuasa Bendahara Umum Daerah. 
Peningkatan penerimaan pajak penghasilan terutama pemungutan dan pemotongan pajak oleh bendahara pemerintah ini juga disebabkan oleh karena para pegawai pajak yang bertugas mengawasi langsung wajib pajak atau yang disebut dengan Account Representative, melakukan pengawasan langsung dan melekat kepada bendahara-bendahara pemerintah yang berada dibawah KPP Pratama Manado. Para AR tersebut secara intensif melakukan sosialisasi dan penyuluhan mengenai pajak bendaharawan, dan juga melakukan pengawasan mengenai kebenaran pemungutan/pemotongan dan penyetoran pajak yang dilakukan oleh para bendahara pemerintah tersebut. Oleh karena itu, dengan adanya pengawasan melekat oleh Kantor Pelayanan Pajak Pratama Manado maka penerimaan pajak dari sector pemerintah dapat meningkat dengan signifikan.

Pada tahun 2017, terdapat penurunan penerimaan pajak penghasilan yang diikuti dengan penurunan pemungutan/pemotongan pajak. Penurunan penerimaan pajak penghasilan diakibatkan oleh karena berakhirnya masa Pengampunan Pajak (Tax Amnesty) pada tanggal 31 Maret 2017, yang mengakibatkan penyetoran pajak untuk Pengampunan Pajak juga berkurang setelah mengalami peningkatan yang cukup drastis pada tahun 2016. Namun, berbeda dengan penurunan penerimaan pajak penghasilan secara keseluruhan, penurunan pemungutan/pemotongan pajak penghasilan oleh bendahara pemerintah disebabkan karena dikeluarkannya Peraturan Menteri Keuangan Republik Indonesia Nomor 101/PMK.010/2016 tentang Penyesuaian Besarnya Penghasilan Kena Pajak. Sebagai akibat dari adanya perubahan PTKP tersebut, maka pemungutan/pemotongan pajak penghasilan pasal 21 untuk pegawai/karyawan mengalami penurunan secara signifikan.

\section{KESIMPULAN DAN SARAN \\ 5.1. Kesimpulan}

Kesimpulan dari penelitian ini adalah kontribusi pemungutan/pemotongan pajak oleh bendahara pemerintah pada Kantor Pelayanan Pajak Pratama Manado Tahun 2013-2017 dinyatakan bahwa sangat mempunyai kontribusi.

\subsection{Saran}

Saran yang dapat diberikan oleh peneliti adalah:

Bagi Kantor Pelayanan Pajak Pratama Manado. Diharapkan agar mampu harus melakukan hal-hal guna meningkatkan penerimaan pajak dari sektor bendaharawan pemerintah. Salah satunya adalah dengan meningkatkan pengawasan terhadap kebenaran penghitungan tarif pajak, kebenaran pemungutan/pemotongan pajak dan kebenaran penyetoran pajak, serta melakukan sosialisasi perpajakan khusus kepada bendaharawan pemerintah.

Bagi peneliti selanjutnya. Peneliti selanjutnya disarankan agar menambah variabel lain yang tidak diteliti dalam penelitian ini seperti tugas dan fungsi Account Representative, sanksi perpajakan dan pengetahuan perpajakan wajib pajak.

\section{DAFTAR PUSTAKA}

Bawasir, F. 1999. Peranan dan Strategi Keuangan di Daerah. Jakarta. Gramedia. Direktorat Jenderal Pajak, 2016. Bendahara Mahir Pajak Edisi Revisi 2016.

Kasim, Chindy Vindy Lissy. 2016. Perhitungan, Pemungutan Dan Penyetoran Pajak Penghasilan (PPh) Pasal 22 Atas Belanja Barang Pada KOREM 131 Sandiago Manado. Jurnal EMBA Vol. 4 No. 1 Maret 2016, 546-557.

Mardiasmo. 2016. Perpajakan Edisi Terbaru 2016. Yogyakarta: Penerbit ANDI. 
Salim, Michel dan Syafitri, Lili. 2013. Analisis Pengaruh Kenaikan PTKP Terhadap Penerimaan Pajak Penghasilan Pada Kantor Pelayanan Pajak Pratama Palembang Ilir Barat. Jurnal Akuntansi STIE MDP.

Sari, Diana. 2013. Konsep Dasar Perpajakan Cetakan Kesatu. Bandung: Refika Aditama.

Sukrainisih, Kadek dan Fajriana, Icha. 2017. Analisis Kontribusi Pemungutan Pajak AlatAlat Berat Dalam Meningkatkan Penerimaan Pendapatan Asli Daerah Di Provinsi Sumatera Selatan. Jurnal Akuntansi Multi Data Palembang.

Suwardjono, 2014. Akuntansi Pengantar Edisi 3. Yogyakarta: Penerbit BPFE.

Tumbel, Arnestha. 2017. Evaluasi Mekanisme Pemotongan dan Pelaporan Pajak Oleh Bendaharawan Pemerintah Pada Badan Perencanaan Penelitian Dan Pembangunan Kabupaten Minahasa Selatan. Jurnal Riset Akuntansi Going Concern 12(2), 2017, 553-564.

Wahyuni.2016. Analisis Pemahaman Dan Kesadaran Bendahara Pemerintah Terhadap Kewajiban Perpajakan (Studi Kasus di UIN Alauddin Makassar). Skripsi. Fakultas Ekonomi dan Bisnis Islam. UIN Alauddin Makassar.

Yulaika, Ruslina. 2014. Pengaruh Sistem Pemungutan Pajak Dan Tarif Pajak Terhadap Efektifitas Pajak Reklame Bagi Toko Di Kabupaten Ngawi. Jurnal Ilmiah STKIP PGRI Ngawi Vo. 13 No. 1(2014) p113-p120. 